\title{
EXPLOITATION OF BUSINESS OPPORTUNITES: THE ROLE OF THE VIRTUAL ENTERPRISE BROKER
}

\author{
Arturo Molina, Myrna Flores \\ CSIM-ITESM Ave. Eugenio Garza Sada 2501 Sur \\ Monterrey, N.L. 64849 MEXICO \\ +52 (8) 358-2000 Ext. 5115, fax:+52 (8) 328-41-23 \\ armolina@campus.mty.itesm.mx,.myrna.flores@gemmc.ge.com
}

\begin{abstract}
In the Framework for Global Virtual Business proposed by the COSME network, a Virtual Enterprise Broker and Virtual Industry Clusters form a Virtual Organisation. The main objective of a Virtual Organisation is to create Virtual Enterprises to exploit business opportunities identified by the Virtual Enterprise Broker using core competencies deployed from partners from different Virtual Industry Clusters. Virtual Enterprise Brokers (VEB's) will need to do much more than just the identification of market needs. The VEB is in charge of identifying, selecting and qualifying best partners for the Virtual Enterprise. Also the responsibility will be to manage the partners' competencies. The objective of this paper is to propose a business model to exploit global business opportunities by VEB based in four main processes: ideation, basic development, advanced development and launching. These four main processes will describe all the activities and tasks that should be performed by the VEB's in order to fulfil market requirements successfully through the Virtual Enterprise concept. Finally, a case study is presented to demonstrate how the VEB using a Virtual Industry Clusters share and deploy companies' competencies in other to satisfy market demands.
\end{abstract}

\section{INTRODUCTION}

A framework was developed by the $\operatorname{COSME}^{1}$ network to better understand how Virtual Enterprises works. The Framework for Global Virtual Business is composed of three main business entities: Virtual Industry Clusters (VIC's), Virtual Enterprise Broker (VEB) and Virtual Enterprise (VE). Each one of these business entities has been defined as follows (Molina et. al 1998):

${ }^{1}$ COSME (Cooperation for Small and Medium Enterprises) network: University of São Paulo, Brazil; Monterrey Institute of Technology, Mexico; Aachen University of Technology, Germany; University of Saint Gallen (Institute of Technology Management), Switzerland; University of Venice, Italy and University of Newcastle upon Tyne, England. 
1. Virtual Industry Cluster (VIC): aggregation of companies from diverse industries, with well defined and focused competencies, with the purpose of gaining access to new markets and business opportunities by leveraging their resources.

2. Virtual Enterprise Broker (VEB): this business entity is responsible for searching opportunities in the global environment and enables the creation of Virtual Enterprises. The Virtual Enterprise Broker performs the processes of partner search and partner selection, and configures suitable infrastructures for VE formation/commitment (physical, legal, social/cultural, information). To achieve its goal the VEB uses the services provided by Virtual Industry Clusters.

3. Virtual Enterprises (VE): temporary networks of independent companies, linked by information technology, which share competencies, infrastructure and business processes, with the purpose to fulfil a specific market requirement.

This paper describes the different business opportunities that a Virtual Enterprise Broker might find in a global market. The core processes and core competencies that the Virtual Enterprise Broker entity will require to realise these business opportunities are presented. Finally a case of study is illustrated to demonstrate the importance of the role that the VEB has in exploiting global business opportunities.

\section{THE VIRTUAL ENTERPRISE BROKER BUSINESS ENTITY}

The Virtual Enterprise Broker (VEB) exploits business opportunities through the creation of Virtual Enterprises (VEs). In order to exploit a business opportunity the VEB should be able to develop products using the competencies of companies that belong to Virtual Industry Clusters (VICs). Therefore a Virtual Enterprise Broker has one core product: Virtual Enterprises which will design and/or manufacture products to satisfy business opportunities.

To achieve this objective the VEBs should use information provided by VICs. Based on this information VEBs are able to search and select partners with the correct competencies for the formation of VEs. The success of a VEB relies on how many successful Virtual Enterprises have been created and how many business opportunities have been generated for specific Virtual Industry Clusters.

In order to create VEs, the Core Processes of a VEB are related to the organization and deployment of competencies of members of VICs in order to create, organize and integrate partners in a VE. The VEB has also the responsibility of configuring the adequate infrastructure for the successful operation and dissolution of VEs.

The most important core competence that a VEB should posses is the ability to integrate the competencies of partners into successful VEs that meet customer's requirements. In order to be successful in the Global Business Environment, the VEB has to build its own competencies concerning competitive advantages, strategic focus or technological capabilities. The VEB should decide how a VE will differentiate from its competitors, for example by providing complete product chain 
processes, taking geographical advantage from suppliers, procuring best business practices or specialized technology (engineer knowledge, high end technology).

Important issues that have to be resolved in order to clarify the role of Virtual Enterprise Brokers in a Global Virtual Business Environment are:

- How to identify business opportunities in a global environment?

- How to match business opportunities with competencies of Virtual Industry Clusters?

- How to analyze customer requirements to find the competencies needed to form the Virtual Enterprise?

- How to design, configure and integrate companies in Virtual Industry Cluster to create Virtual Enterprises?

In the following sections these issues have been addressed and explained in order to understand better the important role of the VEB for exploiting business opportunities.

\subsection{Business Opportunities for the Virtual Enterprise Broker}

For the Virtual Enterprise Broker it is important to analyse business opportunities through the Product Life Cycle (PLC). This analysis will provide insights into the products' competitive dynamics. The PLC curve is typically divided into four stages (Levitt 1965):

1. Introduction: when the product is first introduced in the market, its sales will experience a low to moderate volume growth.

2. Growth: A period of rapid market acceptance and substantial profit improvement

3. Maturity: A period of slowdown in sales growth because the product has achieved acceptance by most potential buyers. Profits stabilise or decline because of increased marketing outlays to defend the product against competition.

4. Decline: The period when sales show a downward drift and profits erode.

VEB's could identify the following business opportunities that might occur in a global business environment using the PLC analysis:

1. If an existing product manufactured by an OEM (Original Equipment Manufacturer) is in its maturity stage, then an opportunity can be satisfied by the VEB though the creation of a Virtual Enterprise, where a set of low-cost suppliers could be searched in a Virtual Industry Cluster (VIC), and then incorporated into the OEM's supply chain. These business opportunities will focus in cost reductions.

2. Repositionings in niche markets could exist when a product is about to reach its decline stage, therefore there is the need to identify a new market, probably in another part of the world, where the product can be successfully introduced and a new life cycle can begin. In this new market, the product will be then in 
the introduction phase. This can be done because in this global economy, when a product is on its decline stage, it could be successfully introduced in another market where the necessity is identified.

3. If an existing product is in its growth stage, a business opportunity can be related to obtain better attributes and functionality in order to cope with the product changes until a dominant design is reached. This business opportunity can be classified as product improvements.

4. If a business opportunity or new product is completely new in the global markets, then it will be in the introduction stage. The VEB will be in charge to develop and deliver this new product to the world.

It could be stated that Virtual Enterprises can be created by VEB's to satisfy these four different kinds of business opportunities, and that its potential success is linked to the product life cycle (Figure 1). Table 1 proposes a definition for each one of these opportunities and suggests different ways to exploit them (adopted form Cooper, 1993).

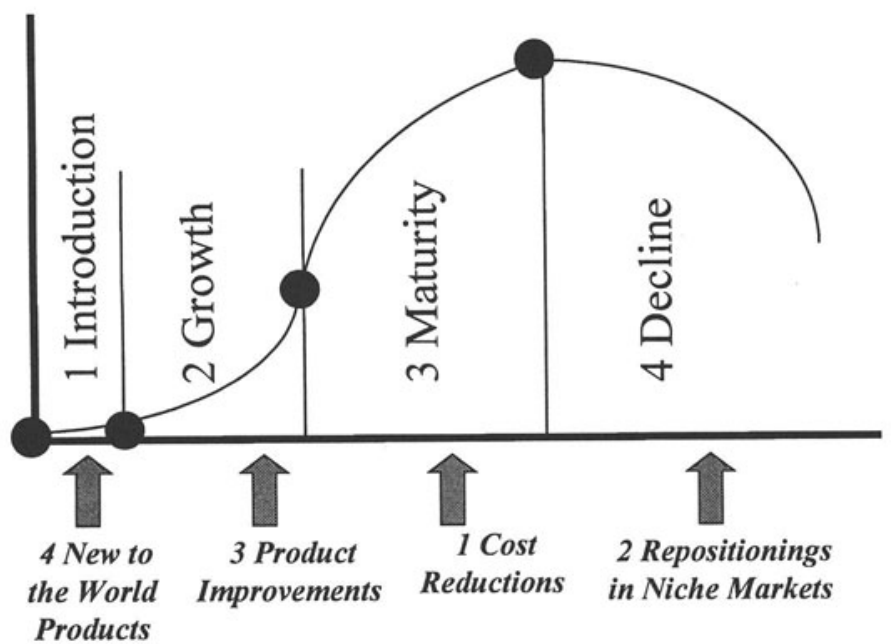

Figure 1 - Business Opportunities to be exploited by the VEB and their relationship to the Product Life Cycle. 
Table 1 - Types of Business Opportunities to be exploited by the VEB (adapted from Cooper, 1993)

\begin{tabular}{|c|c|c|}
\hline $\begin{array}{l}\text { Type of Business } \\
\text { Opportunities }\end{array}$ & Definition & $\begin{array}{l}\text { Example of Business } \\
\text { Opportunities Exploitations }\end{array}$ \\
\hline $\begin{array}{ll}\text { 1. } & \text { Cost } \\
\text { reductions }\end{array}$ & $\begin{array}{l}\text { These business } \\
\text { opportunities arise } \\
\text { because OEM's are } \\
\text { continuously looking for } \\
\text { low cost suppliers. } \\
\text { Therefore the opportunity } \\
\text { is to find in different } \\
\text { Virtual Industry Clusters } \\
\text { partners who can meet the } \\
\text { target cost specified by } \\
\text { the OEMs. }\end{array}$ & $\begin{array}{l}\text { Outsource manufacturing } \\
\text { processes to emerging } \\
\text { economies with lower costs } \\
\text { for human resources } \\
\text { Identify different } \\
\text { manufacturing processes to } \\
\text { produce the same product at } \\
\text { lower cost }\end{array}$ \\
\hline $\begin{array}{l}\text { 2. Repositionings } \\
\text { in niche } \\
\text { markets }\end{array}$ & $\begin{array}{l}\text { The VEB will pursue } \\
\text { these business } \\
\text { opportunities by } \\
\text { searching for new } \\
\text { markets for products that } \\
\text { are in the their last stage } \\
\text { of the product life cycle } \\
\text { (maturity-decline). }\end{array}$ & $\begin{array}{l}\text { Look new markets for } \\
\text { products that are in their } \\
\text { decline stage. }\end{array}$ \\
\hline $\begin{array}{ll}\text { 3. } & \text { Product } \\
\text { improvements }\end{array}$ & $\begin{array}{l}\text { These products offer } \\
\text { improvement } \\
\text { performance or greater } \\
\text { perceived value over } \\
\text { existing products. They } \\
\text { often involve incremental } \\
\text { innovation to an existing } \\
\text { product in order to } \\
\text { achieve a dominant } \\
\text { product design. }\end{array}$ & $\begin{array}{l}\text { Identify similarities among } \\
\text { existing products and } \\
\text { perform changes in those } \\
\text { products to improve their } \\
\text { performance. } \\
\text { Redesign the product, with } \\
\text { less parts or different } \\
\text { materials to increase its } \\
\text { functionality and change its } \\
\text { image. } \\
\text { Improve configurations of } \\
\text { products in order to create a } \\
\text { dominant architecture } \\
\text { (design). }\end{array}$ \\
\hline $\begin{array}{l}\text { 4. New to the } \\
\text { world }\end{array}$ & $\begin{array}{l}\text { Introducing complete new } \\
\text { products to the global } \\
\text { market. }\end{array}$ & $\begin{array}{l}\text { Design a new product from } \\
\text { the start, create a prototype, } \\
\text { discover the market approval } \\
\text { and its new launch to the } \\
\text { market }\end{array}$ \\
\hline
\end{tabular}




\subsection{The Virtual Enterprise Broker Core Processes}

The VEB needs to perform four core processes in order to exploit the business opportunities described above. To achieve this, the processes are based on the concept of new product development. The model proposes four main processes: ideation, basic development, advanced development and launching (Cooper, 1993). Table 2 shows the main inputs, activities to be performed and outputs in each process.

Table 2 - Inputs, main activities and outputs for each process to be performed by the VEB

\begin{tabular}{|c|c|c|c|c|}
\hline & Ideation & $\begin{array}{c}\text { Basic } \\
\text { Development }\end{array}$ & $\begin{array}{c}\text { Advanced } \\
\text { Development }\end{array}$ & Launching \\
\hline $\begin{array}{l}\text { I } \\
\mathbf{N} \\
\mathbf{P} \\
\mathrm{U} \\
\mathrm{T} \\
\mathrm{S}\end{array}$ & $\begin{array}{l}\text { New ideas or } \\
\text { trends for } \\
\text { business } \\
\text { opportunities }\end{array}$ & $\begin{array}{l}\text { Potential idea } \\
\text { with high } \\
\text { business } \\
\text { potential for } \\
\text { development }\end{array}$ & $\begin{array}{l}\text { Approved concept } \\
\text { and identified } \\
\text { potential partners } \\
\text { from VIC's }\end{array}$ & $\begin{array}{l}\text { - New product } \\
\text { prototype }\end{array}$ \\
\hline $\begin{array}{l}\mathbf{A} \\
\mathbf{C} \\
\mathbf{T} \\
\mathbf{I} \\
\mathbf{V} \\
\mathbf{I} \\
\mathbf{T} \\
\mathbf{I} \\
\mathbf{E} \\
\mathbf{S}\end{array}$ & $\begin{array}{l}\text { - Identify markets } \\
\text { needs and trends } \\
\text { and generate ideas } \\
\text { for business } \\
\text { opportunities } \\
\text { continuously } \\
\text { - Classify ideas } \\
\text { regarding its } \\
\text { relationship to the } \\
\text { product life cycle } \\
\text { Select ideas with } \\
\text { the highest market } \\
\text { potential } \\
\text { - Identify processes } \\
\text { and technologies } \\
\text { for the idea } \\
\text { development, its } \\
\text { complexity and } \\
\text { risk to be } \\
\text { produced and } \\
\text { launched } \\
\text { Define a } \\
\text { preliminary } \\
\text { product cost }\end{array}$ & $\begin{array}{l}\text { - Translate the } \\
\text { idea into a new } \\
\text { concept: identify } \\
\text { main attributes } \\
\text { and } \\
\text { specifications } \\
\text { - Contact VIC to } \\
\text { identify potential } \\
\text { partners in } \\
\text { clusters } \\
\text { (products, } \\
\text { processes or } \\
\text { technologies) to } \\
\text { transform the } \\
\text { concept into a } \\
\text { product } \\
\text { - Create concept } \\
\text { business plan } \\
\text { - Perform a risk } \\
\text { analysis for the } \\
\text { concept } \\
\text { - Contact potential } \\
\text { partners from the } \\
\text { different VIC's }\end{array}$ & $\begin{array}{l}\text { - Negotiate with } \\
\text { potential partners } \\
\text { - Evaluate potential } \\
\text { partners from the } \\
\text { VIC's and select } \\
\text { the best } \\
\text { - Integrate partners } \\
\text { and create a new } \\
\text { Virtual Enterprise } \\
\text { - Finish concept } \\
\text { business plans } \\
\text { integrating } \\
\text { partners } \\
\text { capability, costs } \\
\text { and delivery times } \\
\text { Develop a first } \\
\text { prototype with the } \\
\text { selected partners } \\
\text { Create a detailed } \\
\text { production plan } \\
\text { Manufacture first } \\
\text { product batch }\end{array}$ & $\begin{array}{l}\text { - Produce the } \\
\text { product } \\
\text { volume } \\
\text { needed by } \\
\text { the market } \\
\text { - Evaluate } \\
\text { new product } \\
\text { performance } \\
\text { in the market } \\
\text { - Evaluate } \\
\text { partners and } \\
\text { give them } \\
\text { feedback } \\
\text { - Measure the } \\
\text { Virtual } \\
\text { Enterprise } \\
\text { overall } \\
\text { performance } \\
\text { and identify } \\
\text { key learning } \\
\text { points and } \\
\text { opportunity } \\
\text { areas }\end{array}$ \\
\hline $\begin{array}{l}\mathbf{O} \\
\mathbf{U} \\
\mathrm{T} \\
\mathbf{P} \\
\mathbf{U} \\
\mathrm{T}\end{array}$ & - Selected ideas & $\begin{array}{l}\text { - Concept } \\
\text { approved } \\
\text { - Concept design } \\
\text { - Identified } \\
\text { potential } \\
\text { partners from the } \\
\text { different VIC's }\end{array}$ & $\begin{array}{l}\text { - New product } \\
\text { prototype } \\
\text { - Created Virtual } \\
\text { Enterprise } \\
\text { - Production Plan } \\
\text { - First production } \\
\text { batch }\end{array}$ & $\begin{array}{l}\text { Business } \\
\text { opportunity } \\
\text { launched to } \\
\text { the market } \\
\text { by the } \\
\text { Virtual } \\
\text { Enterprise }\end{array}$ \\
\hline
\end{tabular}




\subsection{The Virtual Enterprise Broker Core Competencies}

The concept of Core Competencies have been defined as: "core competencies are the collective learning in the organisation, especially how to co-ordinate diverse production skills and integrate multiple streams of technologies ..." (Prahalad and Hamel 1990, pag. 82). Core competencies are resources and capabilities that serve as a source of competitive advantage for a firm over its rivals (Day et. al., 1997). Core competencies emerge over time through an organisational process of accumulating and learning how to deploy different resources and capabilities. As a capacity to take action, core competencies are the essence of what makes an organisation unique in its ability to provide value to customers over a long period of time (Barton et al, 1994). Also, Hamel (1994) has defined three levels of abstractions related to Core Competencies:

- Meta-Core Competences: is the highest level of abstraction for a competence, this is usually the type of Core Competence one recognise of a company, for example: Logistics in the case of FedExp, Innovation in the case of $3 \mathrm{M}$ or Engineering Excellence for Daimler-Benz

- Core Competencies: this is the system level of a competence where the aggregation of constituent skills conforms a competence. For example Package tracking of FedExp, the culture of innovation of 3M, Cross Functional Engineering knowledge in Daimler-Benz.

- Constituent Skills: these are the basic capabilities of a company when putting together can compose core Competencies: Distribution Technologies of FedExp (e.g. Bar Coding), the practice of the $15 \%$ rule in $3 \mathrm{M}$, Information Technologies of Daimler-Benz.

The meta-level definition is at a level of abstraction where it becomes difficult to work where there is a need to define a useful structure of Core Competencies required for the VEB. Hence this research has concentrated in representing the last two abstraction levels: Core Competencies and Constituent Skills (in this paper named Core Technological Capabilities).

Therefore, the Core Competencies required by the Virtual Enterprise Broker are related to their abilities to:

- Create Virtual Enterprises that will make products to satisfy business opportunities

- Perform a set of business process to design, configure and create Virtual Enterprises

- Apply or have access to core technological capabilities (human resources, organisation, and technological resources) for developing and creating Virtual Enterprises, which will design and manufacture products to exploit business opportunities.

Hence a set of core technological capabilities needed to develop Virtual Enterprises for the VEB are: 
- Human resources: people with knowledge and expertise to identify the required competencies in companies to develop products, and also staff with technical/management skills and leadership abilities to create Virtual Enterprises.

- Organisation aspects: organisational structures and methods required to better use the knowledge, skills and abilities of the Broker team.

- Technological resources: computer tools that can be used to support the development of Virtual Enterprises.

The Virtual Enterprise Brokers uniqueness will emerge by the integration of core competencies required to create Virtual Enterprises using the best organisational structure, methods and computer tools.

\subsubsection{Human Resources and Organisation of the Virtual Enterprise Broker}

In order to manage the VEB business entity, three different roles will be needed:

1. The Broker Competence Manager, will coordinate all the VEB activities, will give feedback to the business opportunity brokers and will have the VEB business entity full responsibility.

2. The Business Opportunity Broker, will takes care of an specific business opportunity through its four processes: ideation, basic development, advanced development and launching This kind of broker within the VEB organisation, will have the direct contact with the customer or market who needs new products. It is important to mention that the business opportunity broker can develop several opportunities at the same time.

3. Process Specialist will be in charge of fulfilling all the activities in one specific process, 1) ideation, 2) basic development, 3) advanced development or 4) launching. This specialist will need to deliver his outputs to the business opportunity broker who is in charge of the complete business opportunity development and will deliver these outputs to the next broker process specialist. Finally, for the successful development of the business opportunities, several broker processes specialists can work in the same process forming a multidisciplinary team.

Figure 2 shows the relationships among these three different persons within the Virtual Enterprise Broker business entity. 


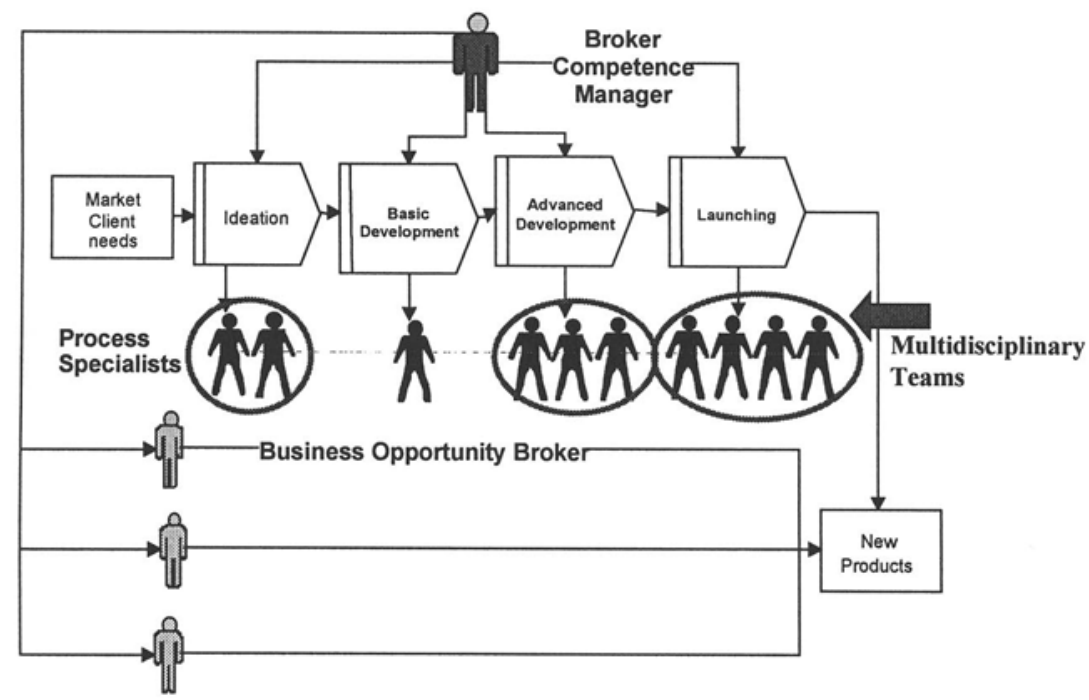

Figure 2. VEB business entity organisation and its human resources relationships.

In order to construct the best organisation within the VEB business entity, skills and abilities needed for the three previous roles have to be defined, so the persons chosen for each role can fulfil the needs that each role requires. Table 3 shows an example of the general abilities and skills identified for the Broker Competence Manager to manage in a successful way the VEB business entity.

Table 3 - Broker Competence Manager Skills and Abilities

\section{Broker Competence Manager skills and abilities}

\section{Leadership abilities:}

- Charismatic: Ability to act as a model, to get people follow him, demands respect and loyalty to his/her people, has trust and faith in him in the way he handles the problem.

- Inspirational: Ability to make the team follow his ideas about missions and visions. Believes in his methods \& ways to accomplish.

- $\quad$ Stimulate: Encourage people to think in new and creative ways and do things in different or better ways.

\section{Skills}

- Demonstrated leadership: tolerant, gives feedback, people handling, administrative skills, getting things done, involvement in creativity process, strong communicator, etc.

- Analytically driven: good intuition, entrepreneurial instincts, vision \& positive mental mindset.

- Established manager: Sensibility to internal culture, confidence \& respect to colleagues commands respect and trust, reliable and fair. 


\subsubsection{Technological resources of the Virtual Enterprise Broker}

The third core technological capability needed in the VEB business entity are the tools that will enable these brokers and the partners in the Virtual Industry Cluster to collaborate together. The following four main tools were identified:

- Co-ordination tools to help Broker Competence Manager to co-ordinate other brokers in the business opportunities developments.

- Communication tools to help Brokers and specialists to organise their tasks and activities.

- Co-operation tools: to help Brokers and specialists to share data/information required for Virtual Enterprise development.

- Applications to support specialised activities: to help specialists to perform their activities related to product and Virtual Enterprise development.

Table 4 shows the different tools that could be used by the different brokers within the VEB organisation and several examples of tools.

Table 4 - Technological Resources needed in the VEB Business Entity

\begin{tabular}{|c|c|c|}
\hline Broker Type & Tools to be used & Example of Tools \\
\hline $\begin{array}{l}\text { Broker } \\
\text { Competence } \\
\text { Manager }\end{array}$ & $\begin{array}{l}\text { - } \quad \text { Co-ordination Tools } \\
\text { - } \quad \text { Communication Tools }\end{array}$ & $\begin{array}{l}\text { - } \\
\text { - } \quad \text { Groject Management Software } \\
\text { - }\end{array}$ \\
\hline $\begin{array}{l}\text { Business } \\
\text { Opportunity } \\
\text { Broker }\end{array}$ & $\begin{array}{ll} & \text { Co-operation Tools } \\
\text { - } & \text { Co-ordination Tools } \\
\text { - } & \text { Communication Tools } \\
\text { - } & \text { Applications to } \\
& \text { support specialised } \\
& \text { activities }\end{array}$ & $\begin{array}{ll}\text { - } & \text { Computer Supported Co- } \\
\text { operative Work } \\
\text { - } \\
\text { Project Management Software } \\
\text { - WroupWare and Workflow } \\
\text { databases, data mining software, } \\
\text { case based learning tools, } \\
\text { configuration and planning } \\
\text { tools. }\end{array}$ \\
\hline $\begin{array}{l}\text { Process } \\
\text { Specialist }\end{array}$ & $\begin{array}{ll}\text { - } & \text { Co-operation Tools } \\
\text { - } & \text { Communication Tools } \\
\text { - } & \text { Applications to } \\
\text { support specialised } \\
\text { activities }\end{array}$ & $\begin{array}{l}\text { Computer Supported Co- } \\
\text { operative Work } \\
\text { - } \text { GroupWare and Workflow } \\
\text { Web agents, information } \\
\text { databases, data mining software, } \\
\text { case based learning tools, } \\
\text { control and monitoring tools. }\end{array}$ \\
\hline
\end{tabular}

\section{CASE STUDY: EXPLOITING BUSINESS OPPORTUNITIES FOR VIRPLAS}

VIRPLAS, which stands for VIRtual industry cluster for PLAStics, was created to explore how the concept of Virtual Industry Cluster could enhance the regional development of the plastic industrial sector of Monterrey, Mexico (Flores and 
Molina 2000). VIRPLAS has six members with different competencies within the plastic industry. One company is focused on product and mould design, another has capabilities to design and manufacture injection moulds components, two companies are on the business of injection moulding, and one company is specialized in commercialisation of plastic products and machinery. All these companies are Small and Medium Enterprises (SMEs) with high interest in being part of the new global businesses.

VIRPLAS has the competence to design, develop and produce plastic products. In this case the product to be produced is a plastic part for a new washing machine that needs to be sent as soon as possible to the customer. The OEM (Original Equipment Manufacturer) does not have available capacity to produce these parts at the moment in its factory. The OEM is looking for a low-cost supplier to manufacture this component. The VEB of VIRPLAS has identified this type of business opportunity. As the product to be manufactured is a new part design, which is a component of a washing machine to be assembled by an OEM, this opportunity can be categorised as 1) cost reductions or as 2) product improvement. However, as the objective of the OEM is to outsource the component until the capacity is installed in the OEM plant at the lowest cost possible, it will be then classified as a cost reduction opportunity.

The VEB will organise the different VIRPLAS members to take advantage of this opportunity. One of the six members core competence is product design and mould fabrication, so partner $\boldsymbol{A}$ will be in charge of the part design. As the needed volume of the OEM is really high and the VIRPLAS members are SMEs, two members of VIRPLAS who produce injected parts will be needed to produce the needed volume. Partner $\boldsymbol{B}$ and Partner $\boldsymbol{C}$ will receive the mould from Partner A and then they will manufacture the parts. As soon as the parts are manufactured they will be sent to the OEM. This will be done for six months, and as soon as the OEM installs the needed capacity, this Virtual Enterprise will be dissolved. Table 5 shows how this Virtual Enterprise will perform these activities though the four VEB core processes.

Table 5 - Business Opportunity creation with VIRPLAS

\begin{tabular}{|c|c|c|c|c|}
\hline & Ideation & $\begin{array}{l}\text { Basic } \\
\text { Development }\end{array}$ & $\begin{array}{c}\text { Advanced } \\
\text { Development }\end{array}$ & Launching \\
\hline $\begin{array}{l}\text { VEB } \\
\text { Main } \\
\text { Activities }\end{array}$ & $\begin{array}{l}\text { - Business } \\
\text { Opportunity } \\
\text { identified: } \\
\text { Manufacturing } \\
\text { of a washing } \\
\text { machine part } \\
\text { within a time } \\
\text { span of six } \\
\text { months and } \\
\text { with a lower } \\
\text { cost }\end{array}$ & $\begin{array}{l}\text { - VEB contacts } \\
\text { VIRPLAS partners } \\
\text { - OEM specifies } \\
\text { products attributes } \\
\text { and specifications } \\
\text { - The Process } \\
\text { Specialist carries } \\
\text { out a first } \\
\text { prototype using the } \\
\text { capabilities of pre- } \\
\text { selected VIRPLAS } \\
\text { partners }\end{array}$ & $\begin{array}{l}\text { - VEB negotiates } \\
\text { with the pre-selected } \\
\text { VIRPLAS members } \\
\text { - VIRPLAS members } \\
\text { accept to participate } \\
\text { - The new Virtual } \\
\text { Enterprise is formed } \\
\text { with three VIRPLAS } \\
\text { members } \\
\text { - Partner A designs } \\
\text { and fabricate the } \\
\text { mould, Partners B } \\
\text { and C inject the first } \\
\text { parts for OEM trials } \\
\text { and approval. }\end{array}$ & $\begin{array}{l}\text { - Partners B and } \\
\text { C inject the six } \\
\text { months volume } \\
\text { needed by the } \\
\text { OEM } \\
\text { - As soon as the } \\
\text { capacity is } \\
\text { installed in the } \\
\text { OEM plants, the } \\
\text { Virtual } \\
\text { Enterprise } \\
\text { dissolves. }\end{array}$ \\
\hline
\end{tabular}


Table 5-Continuation

\begin{tabular}{|c|c|c|c|c|}
\hline & Ideation & $\begin{array}{l}\text { Basic } \\
\text { Development }\end{array}$ & $\begin{array}{c}\text { Advanced } \\
\text { Development }\end{array}$ & Launching \\
\hline $\begin{array}{l}\text { Virtual } \\
\text { Enterprise } \\
\text { Entities } \\
\text { Interaction }\end{array}$ & $\begin{array}{l}\text { VEB } \\
\text { discovers a } \\
\text { new business } \\
\text { opportunity }\end{array}$ & $\begin{array}{l}\text { VEB identifies } \\
\text { potential partners } \\
\text { and uses their } \\
\text { capabilities. }\end{array}$ & $\begin{array}{l}\text { - Virtual Enterprise } \\
\text { Broker invites } \\
\text { VIRPLAS } \\
\text { members to } \\
\text { participate } \\
\text { Virtual Enterprise } \\
\text { Operation starts }\end{array}$ & $\begin{array}{l}\text { - Virtual Enterprise } \\
\text { Broker deliver } \\
\text { product to OEM } \\
\text { - Virtual Enterprise } \\
\text { Dissolves }\end{array}$ \\
\hline Roles & $\begin{array}{l}\text { - Broker } \\
\text { Competence } \\
\text { Manager } \\
\text { Business } \\
\text { Opportunity } \\
\text { Broker }\end{array}$ & $\begin{array}{l}\text { - Business } \\
\text { Opportunity } \\
\text { Broker } \\
\text { - Process Specialist }\end{array}$ & $\begin{array}{l}\text { Business } \\
\text { Opportunity } \\
\text { Broker } \\
\text { - Process Specialist }\end{array}$ & $\begin{array}{l}\text { - Broker } \\
\text { Competence } \\
\text { Manager } \\
\text { - Business } \\
\text { Opportunity } \\
\text { Broker } \\
\text { - Process Specialist }\end{array}$ \\
\hline $\begin{array}{l}\text { Tools } \\
\text { required }\end{array}$ & $\begin{array}{l}\text { Web agents, } \\
\text { information } \\
\text { databases }\end{array}$ & $\begin{array}{l}\text { - Information } \\
\text { databases, data } \\
\text { mining software }\end{array}$ & $\begin{array}{l}\text { - Case based } \\
\text { learning tools, } \\
\text { configuration and } \\
\text { planning tools }\end{array}$ & $\begin{array}{l}\text { Control and } \\
\text { monitoring tools }\end{array}$ \\
\hline
\end{tabular}

\section{CONCLUSIONS}

The business entity of the Virtual Enterprise Broker (VEB) has been presented, and its relevance to exploit business opportunities in the global market has been explained. The business opportunities have been described based on the concept of product life cycle, which allows to set reference criteria for VEB in order to select the partners for Virtual Enterprises. The core process and core competencies required by the VEB in order to create Virtual Enterprises have been described and discussed in detail. A case of study based on the virtual industry cluster - VIRPLAS was presented in order to demonstrate the applicability of the concepts described in this paper. Next stages in this research will focus on developing detail process models and required software tools to support the activities and tasks of the VEB.

\section{REFERENCES}

1. Barton L., Bowen, Clark, Holloway and Wheelwright, How to integrate work and deeper expertise, Harvard Business review 72, 1994, no 5:124.

2. Cooper G. Robert, Winning at new products, Accelerating the Process from Idea to Launch, EddisonWesley Publishing Company, Second Edition, 1993.

3. Day G.S., Maintaining the competitive edge: Creating and sustaining advantages in dynamic competitive environments, in G.S. Day and D.J Reinstein Eds., 1997, Wharton on Dynamic Competitive Strategy (New York: John Wiley \& Sons), 1997, 48-75.

4. Flores M. and Molina A., "Virtual Industry Clusters: Foundation to create Virtual Enterprises", accepted to be presented at BASYS'2000, September 2000, Berlin, Germany.

5. Hamel G., “The Concept of Core Competence”, In G. Hamel and A. Heene (Eds.), Competence based competition. John Wiley \& Sons, 1994.

6. Levitt, T, “Exploit the Product Life Cycle”, Harvard Business Review, November-December 1965, pp. 81-94.

7. Molina A., Ponguta S., Bremer C.F., Eversheim W., “Framework for Global Virtual Business", Agility \& Global Competition, Vol. 2, No. 3, 1998, pp. 56-69.

8. Prahalad, C.K. and Hamel G.,The core competence of the corporation. Harvard Business Review, May-June, 82, 1990. 